\title{
DIVERSIFIKASI RASA DAN KEMASAN KRUPUK PARU UNTUK MENINGKATKAN PENJUALAN
}

\author{
Fatmawati ${ }^{1}$ \\ Henny Diana Wati² \\ Yayuk Sugiarti ${ }^{3}$
}

Volume 1, Nomor 1, September 2018

Universitas Wiraraja

\begin{abstract}
Utilization of cattle lungs is not only served in the form of side dishes or lung empal. But in the hands of Yasmin women groups located in Kacongan Village and violet women groups located in Parsanga Village, cow lungs are transformed into savory and high economic value snacks so they can provide income in the family. These crackers are not only tasty and of high economic value, but also contain high protein which is very beneficial for the body. This is because protein is essential to play a role in the growth and formation of body tissues. Expected outputs are as follows: (1) The creation of a distinctive taste of cow's lung crackers, which is spicy and cheese-flavored, (2) The packaging of cow lung crackers that is more interesting and unique, (3) Making brands of cow lung crackers produced, and (4) Increased sales of cow lung crackers. The results of the activities showed the enthusiasm of the participants, so this indicated that this activity was exciting.
\end{abstract}

Keyword: Cattle Crackers, Flavor, and Packaging

\section{PENDAHULUAN}

Pemanfaatan paru sapi selama ini tidak hanya di sajikan dalam bentuk lauk atau empal paru. Tetapi di tangan kelompok wanita yasmin yang berlokasi di Desa Kacongan dan kelompok wanita violet yang berlokasi di Desa Parsanga, paru sapi disulap menjadi panganan yang gurih dan bernilai ekonomi tinggi sehingga dapat memberikan pemasukan dalam keluarga. Kerupuk ini tidak hanya gurih dan bernilai ekonomi tinggi, tetapi juga mengandung protein yang tinggi sehingga sangat bermanfaat bagi tubuh. Hal ini dikarenakan protein sangat penting untuk berperan dalam pertumbuhan dan membentuk jaringan tubuh.

Usaha pembuatan kerupuk paru yang dilakukan oleh kelompok wanita yasmin dan kelompok wanita violet sudah mereka tekuni sejak tahun 2000 sampai sekarang. Dengan berjalannya waktu, pesaing mereka semakin banyak. Dengan pesaing yang semakin banyak maka mereka berupaya untuk meningkatkan omzet penjualan dengan cara melakukan diversifikasi rasa dan kemasan kerupuk paru agar tetap eksis dan berkembang. Dengan adanya kegiatan Ipteks bagi Masyarakat $\left(\mathrm{I}_{\mathrm{b}} \mathrm{M}\right)$ ini diharapkan kelompok wanita yasmin dan kelompok wanita violet dapat mendiversifikasikan rasa dan kemasan kerupuk paru sapi serta memasarkannya sehingga usaha yang dilakukan dapat berkembang dan memberikan manfaat kepada masyarakat sekitar.

Melalui program Ipteks Bagi Masyarakat $\left(\mathrm{I}_{\mathrm{b}} \mathrm{M}\right)$ pada Ibu Gina dan Ibu Maisura maka luaran yang diharapkan adalah (1) Terciptanya rasa kerupuk paru sapi yang berbeda dari yang sudah ada yaitu rasa pedas dan rasa keju; (2) Kemasan kerupuk paru sapi yang lebih

\footnotetext{
1 fatmawati.ir@gmail.com

2 hennydianawati@yahoo.co.id

3 yayuksugiarti66@yahoo.co.id
} 
menarik dan unik; (3) Pembuatan merk (brand) dari kerupuk paru sapi yang di produksi; dan (4) Peningkatan penjualan kerupuk paru sapi. Adapun Spesifikasi kerupuk paru sapi yang akan dihasilkan adalah produk kerupuk paru sapi beraneka rasa yang dengan kemasan yang menarik dan unik dalam berbagai kemasan.

\section{METODE}

Kegiatan Pengabdian kepada Masyarakat dilaksanakan selama 8 (delapan) bulan, dimulai dari 7 April sampai dengan 10 Nopember 2014. Tempat pelaksanaan kegiatan di Desa Parsanga dan di Desa Kacongan, Kecamatan Kota Sumenep, Kabupaten Sumenep, Propinsi Jawa Timur. Berdasarkan permasalahan yang dialami, maka Tim PPM IbM Universitas Wiraraja Sumenep, berinisiatif untuk memberikan pendampingan dan pelatihan diversifikkasi rasa dan kemasan kerupuk paru untuk meningkatkan penjualan. Adapun Tahapan pelaksanaan yang direncanakan untuk Program IbM sebagai berikut.

Pertama, Sosialisasi. Sosialisasi dilakukan setelah adanya kepastian dari DP2M Ditjen Dikti tentang kegiatan ini dan dimaksudkan untuk melihat kesiapan lokasi dan sasaran atau mitra sebagai potret awal daerah kegiatan. Kedua, Penyusunan modul pelatihan penerapan $I_{b} M$. Modul pelatihan disusun berdasarkan atas kebutuhan program penerapan IbM yang meliputi, (1) proses pembuatan kerupuk paru sapi, (2) teknik diversifikasi rasa dan kemasan dan (3) analisis usaha. Ketiga, Penyiapan sarana dan prasarana. Sarana dan prasarana yang pelu dipersiapkan pada kegiatan ini meliputi; (1) Alat dan bahan pelatihan; (2) Desain kemasan dan label; (3) Tata ruang/ lay out tempat produksi. Keempat, Pelaksanaan pelatihan. Pada tahap ini mitra akan dilatih agar lebih terampil dalam pembuatan kerupuk paru, baik dari teknik teknik penyiapan bahan dan alat, proses pengolahan, teknik pengemasan sampai kepada perhitungan usaha. Kelima, Pemantauan dan refleksi. Pada saat kegiatan berlangsung, setiap tahapan proses akan dilakukan pemantauan dan dicermati/dikendalikan, sesuai dengan rencana dan tujuan yang telah ditetapkan. Bila terjadi suatu keadaan yang di luar perhitungan, maka akan segera dilakukan langkah penyesuaian dan tindakan perbaikan.

Setelah kegiatan dalam satu siklus/periode selesai, dilakukan refleksi untuk mengevaluasi apakah proses pada setiap tahapan kegiatan dan hasil telah sesuai dengan rencana. Kemudian tindak lanjut apa yang perlu dilakukan. Melalui refleksi/evaluasi ini, Perbaikan-perbaikan yang dilakukan dari hasil refleksi/evaluasi kegiatan ini, akan menjamin terlaksananya program Ipteks bagi Masyarakat (IbM) ini secara berkesinambungan dan berkelanjutan, untuk membentuk kemandirian secara ekonomi, sehingga tercipta suatu kelompok usaha produktif.

\section{PEMBAHASAN}

Pelaksanaan kegiatan $\mathrm{I}_{b} \mathrm{M}$ dilakukan pada 2 (dua) tempat yang berbeda yaitu di dan kelompok wanita violet Desa Parsanga dan kelompok wanita yasmin Desa Kacongan Kecamatan Kota Sumenep. Dalam pelaksanaan kegiatan IbM ini, tim melakukan pelatihan tentang bagaimana cara untuk pembuatan kerupuk paru sapi yang bervariasi dalam segi rasa yaitu rasa pedas dan rasa keju serta cara untuk pengemasan yang baik. Sebelum pelaksanaan pelatihan kepada mitra, tim terlebih dahulu melakukan uji coba pedas dan rasa keju, sehingga ketika pada pelakasanaan kegiatan pelatihan tim dapat benar-benar memberikan yang terbaik, baik dari segi rasa. Dalam setiap pelaksanaan pelatihan selalu 
mendapatkan respon yang positif dari setiap anggota kelompok, baik kelompok wanita yasmin maupun kelompok wanita violet. Hal ini menandakan bahwa diversifikasi rasa kerupuk paru dapat diterima dengan baik oleh kelompok yasmin dan kelompok wanita violet.

Sehingga dengan demikian, hasil dari pelaksaan kegiatan tersebut di ikutkan dalam berbagai even yang ada di Kabupaten Sumenep, diantaranya dalam acara diesnatalis Universitas Wiraraja dan Pameran Pendidikan Pemerintah Kabupaten Sumenep. Dalam setiap even selalu mendapatkan apresiasi dan respon yang sangat baik dari masyarakat.

\section{SIMPULAN}

Kesimpulan yang dapat diperoleh dari pelaksanaan program pengabdian kepada masyarakat IbM di kelompok wanita yasmin Desa Kacongan dan kelompok wanita violet Desa Parsanga menunjukkan respon yang tinggi terhadap kegiatan tersebutyang dilakukan. 